\title{
EGG-LAYING INDUCED BY INSEMINATION IN BIOMPHALARIA SNAILS
}

\author{
W. LOBATO PARAENSE ${ }^{+}$
}

Departamento de Malacologia, Instituto Oswaldo Cruz, Av. Brasi] 4365, 21045-900 Rio de Janeiro, RJ, Brasi]

Contrasting with many populations of Biomphalaria glabrata and B. straminea previously dealt with in this laboratory, which when reared in isolation deposit self-fertilized eggs without apparent restraint, isolated individuals of the former species from São Sebastião do Passé, Bahia state, and of the latter from Porto Alegre, Rio Grande do Sul state, show a high degree of selfsterility, laying egg capsules with a few usually abortive, rarely viable egg cells, or just jellylike masses without egg cells. When two such individuals are paired they readily copulate, usually within $24 \mathrm{hr}$ deposit one or more egg capsules containing many eggs, and egg-laying continues up to exhaustion of stored allosperm. So far this aspect of reproductive biology has been only observed in a number of populations of the planorbid species Helisoma duryi, and should be viewed as a populational rather than specific characteristic. Since sterility is not overcome by courtship, copulation and insemination by individuals of a different species, the stimulating factor that causes ovulation in the studied self-sterile individuals is considered to be present in the conspecific allosperm.

Key words: Mollusca Planorbidae - Biomphalaria glabrata - Biomphalaria straminea Reproductive biology - Self-sterility

In a previous study (Paraense \& Corrêa, 1988) it was observed that specimens of Helisoma duryi from five distant populations in Brazil, Peru, Costa Rica, St Vincent and St Croix, reared in isolation for 150 days, produced small egg capsules containing at most 4 eggs each. The number of eggs laid by 10 specimens from each population were respectively (viable eggs in parentheses): $5(0), 44$ (26), 15 (7), $38(0)$ and 1 (1). As regards the samples from Brazil and St Vincent, these data confirmed the findings of previous authors on the inability of $H$. duryi to reproduce by selfing (DeWitt \& Sloan, 1959; Madsen et al., 1983). As to the samples from Peru, Costa Rica and St Croix, however, a variable although low degree of selfing was observed. Not infrequently wère jellylike masses deposited by snails of any sample, either egg-layers or not. Many such masses contained all components of an egg capsule, including or not albumen vesicles, but without egg cells. When two isolated snails from the same population were paired, several egg capsules containing many

\footnotetext{
${ }^{+}$CNPq Research Fellow.
}

Received 3 May 1993.

Accepted 6 August 1993. eggs were laid by each specimen on the next day after copulation, and egg-laying continued regularly.

Those results were interpreted as indicative that "self-fertilization is not so efficient an alternative mode of reproduction in $H$. duryi as in many other planorbids, e.g. Biomphalaria glabrata". As a matter of fact, all Neotropical species of Biomphalaria so far kept in this laboratory (glabrata, tenagophila, peregrina, straminea, schrammi, intermedia, amazonica, oligoza and occidentalis) had proved efficient self-fertilizers. Further experiments, however, revealed some exceptions to that rule which are reported below.

\section{MATERIAL AND METHODS}

In November 1991 I tried crossing experiments using Biomphalaria glabrata descended from specimens collected from marginal pools along the river Jacuipe at the town of São Sebastião do Passé (SSP), state of Bahia. Contrasting with all previously tested specimens from numerous populations of that species, which when reared in isolation regularly oviposit on reaching about $8 \mathrm{~mm}$ in shell diameter, and proceed laying usually one daily capsule with a number of eggs, the isolated 
SSP snails laid, later than usual (above $10 \mathrm{~mm}$ in diameter), either small capsules with a few eggs, or albumen globules without egg cells, or just the jellylike envelope of the egg capsule. Forty such specimens were paired off into couples for $12 \mathrm{hr}$ and then observed separately for about 100 to 200 days, during which period they were rejoined two or three times. Two of those couples were formed by a homozygous pigmented specimen and an albino (homozygous, of course).

Similar experiments were carried out with 40 Biomphalaria straminea descended from specimens collected from a marshy vacant lot, referred to as "Estação B 10" in DMAE (1975) Report, at the crossing of Bento Gonçalves avenue and Albion street, in Porto Alegre city (POA), state of Rio Grande do Sul, and which when reared in isolation showed the same pattern of egg production as in SSP B. glabrata.

The room temperature varied from $20^{\circ}$ to $31{ }^{\circ} \mathrm{C}$ during the observation period. Snails were fed lettuce.

Egg capsules were deposited on the underside of floating Styrofoam tablets (sometimes on the aquarium wall), from which they were removed to small petri dishes with aquarium water for examination under the stereomicroscope. Eggs were considered inviable when they failed to divide or stopped development at any stage before hatching. Viable eggs, therefore, were those that developed to hatching.
Hatching rate was assessed in about 1,000 eggs from each of 10 specimens of either group kept at $25 \pm 1{ }^{\circ} \mathrm{C}$.

\section{RESULTS}

Fig. 1 is representative of the results of crossing experiments with SSP B. glabrata. One albino specimen, reared in isolation, on reaching $10 \mathrm{~mm}$ in diameter laid a small capsule with a single albumen globule without egg cell. On the following 54 days it laid eight additional capsules: 6 with one albumen globule, 1 with two, and 1 with and inviable egg. On the 55th day ( 0 day of Fig. 1), measuring $14 \mathrm{~mm}$ in diameter, it was mated at 8:00 AM with a pigmented sibling that had previously deposited 19 capsules without egg cells, and copulation readily took place. At 8:00 PM it was separated from its mate, and as of the next morning one or two capsules with 8 to 65 eggs were laid nearly every day up to day 70 , when egg production stopped to be resumed after a second pairing with the same mate on day 79 . Further periods of decline in egg production followed by fertile matings are recorded twice on Fig. 1.

A similar trend was shown by the mate of the specimen of Fig. 1 and by the 38 specimens of the remaining couples. A hatching rate of $91.6 \%$ was recorded among 11,148 eggs from 10 specimens.

A typical result of crossing experiments with POA B. straminea is shown in Fig. 2. The

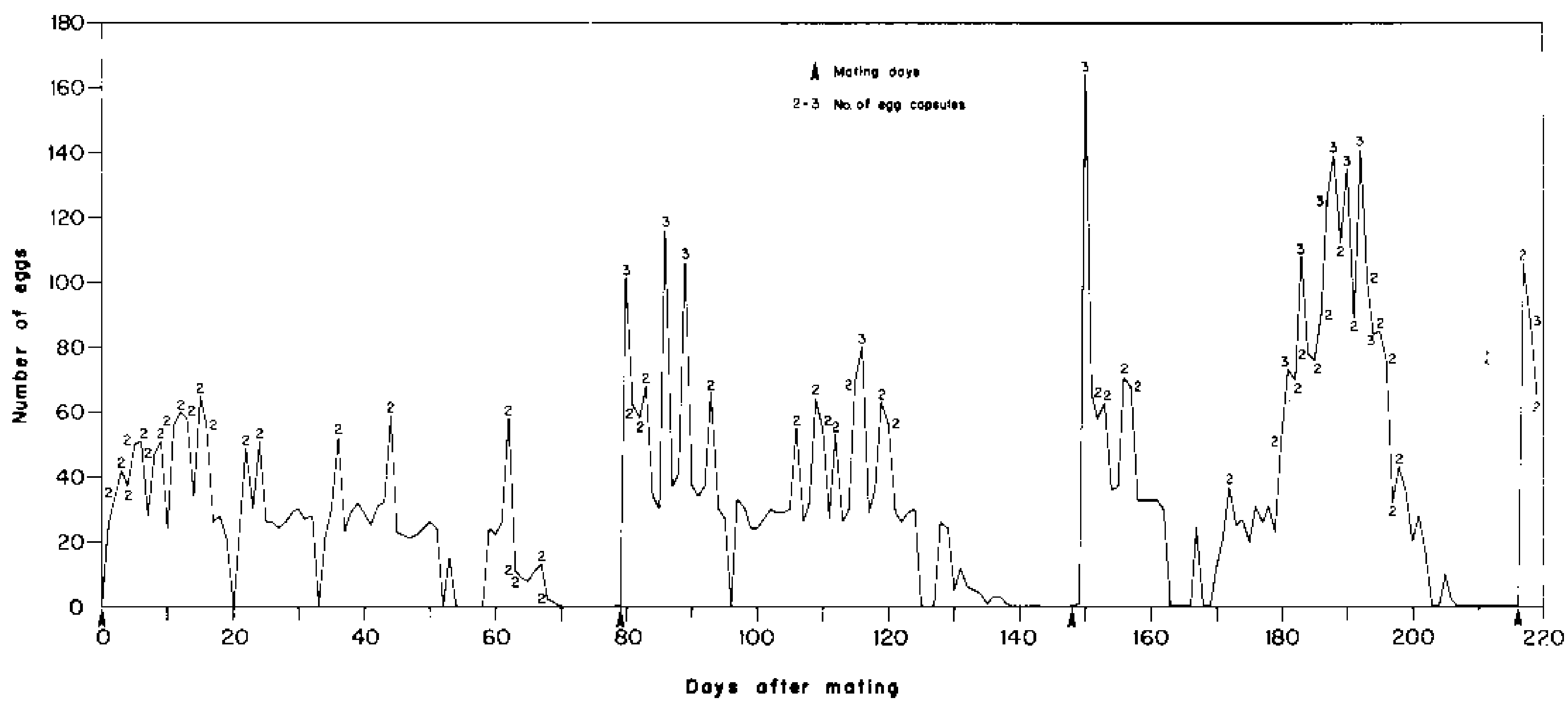

Fig. 1: egg-laying by specimen of Biomphalaria glabrata from Sīo Sebastiāo do Passè, reared in isolation and selfsterile up to 121 days old, when it was mated with a sibling ( 0 day). Oviposition started within $24 \mathrm{hr}$, lasting 69 days up to exhaustion of stored allosperm. Further malings, on days 79,148 and 216 , restablished oviposition for additional periods. 


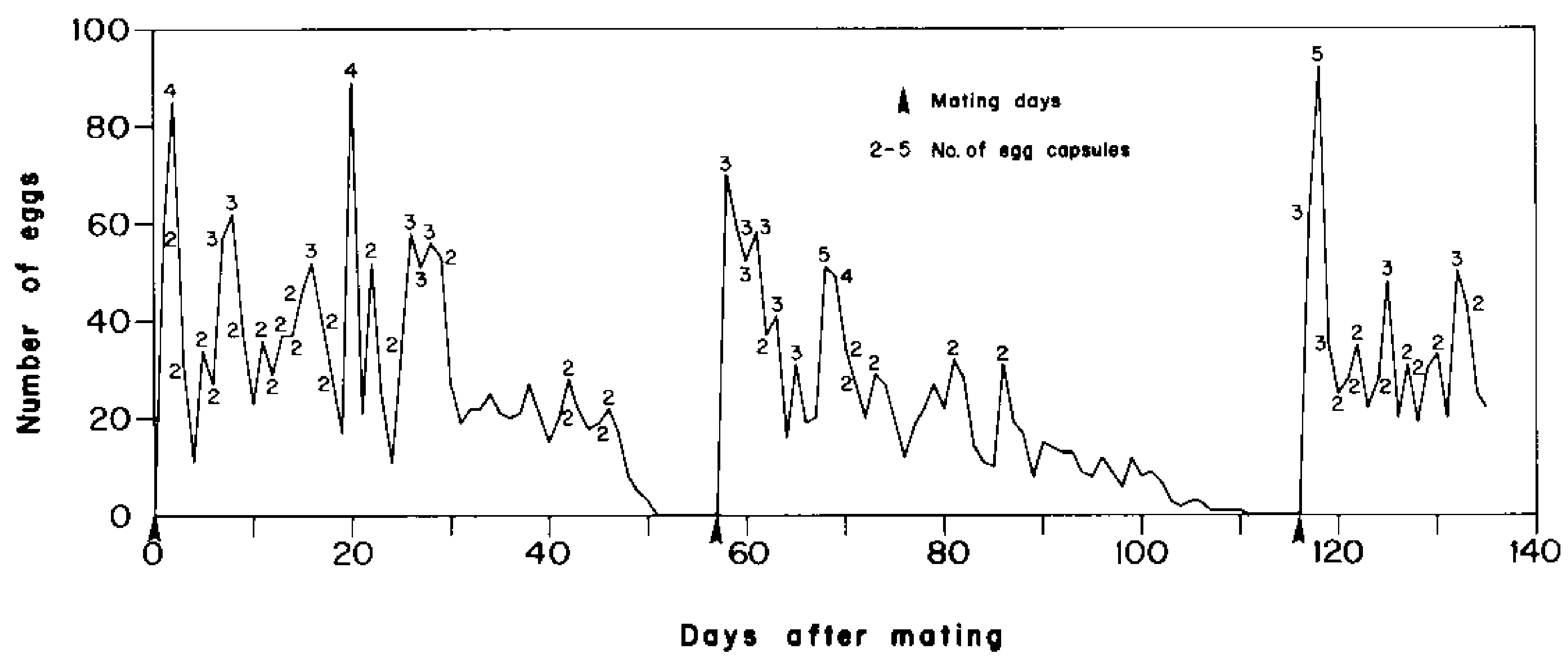

Fig. 2: egg-laying by specimen of Biomphalaria straminea from Porto Alegre, reared in isolation and self-sterile up to 134 days old, when it was mated with a sibling ( 0 day). Oviposition started within $24 \mathrm{hr}$, lasting 46 days. Further matings, on days 57 and 116 , restablished oviposition for additional periods.

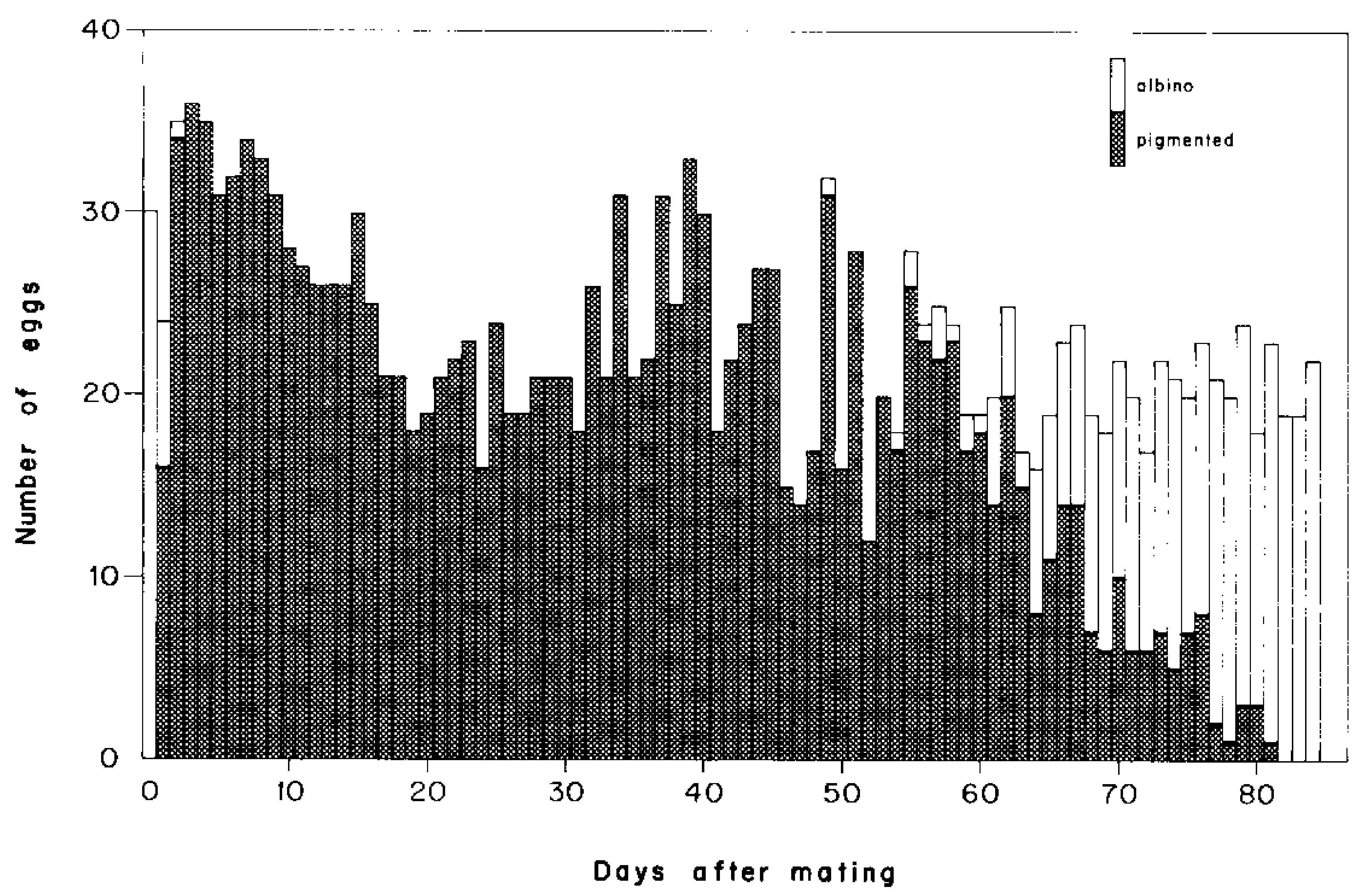

Fig. 3: daily egg-laying by albino Biomphalaria glabrata from Santa Luzia, Minas Gerais state, reared in isolation and producing selfed eggs (developing into albino embryos) up to 0 day, when it was inseminated by a homozygous pigmented mate, and then isolated again. Soon after mating it tumed to cross-fertilization, producing exclusively pigmented embryos from days 3 to 48 . As of day 49 albino embryos appeared in increasing proportion among pigmented ones indicating gradual depletion of allosperm store which became exhausted on day 81 . From day 49 on, the snail made up for the decrease of available allosperm by fertilizing its egg surplus with its own sperm.

specimen in question, reared in isolation, laid no eggs until 134 days old ( $8 \mathrm{~mm}$ in diameter), when it was mated at 8:00 AM with a sibling that had previously deposited five capsules with 1 egg each (3 viable, 2 inviable). Twelve hours later, copulation having occurred, the couple was separated. As with SSP B. glabrata, recurring cycles of egg production immediately after mating, followed by cessation of egg laying, were observed with POA B. straminea. A 
hatching rate of $88.4 \%$ was recorded among 10,243 eggs from 10 specimens.

\section{DISCUSSION}

Self-fertilization has been observed in many families of pulmonate gastropods. Among the Planorbidae (see literature in Paraense \& Corrêa, 1988) selfing is widely practiced by all hitherto investigated species, with the only known exception of Helisoma duryi, in which just a small minority of individuals produce a few viable selfed hatchlings (Paraense \& Corrêa, 1988). To my knowledge, this is the first record of self-sterility in species of the genus Biomphalaria. Such condition, though dominant in the two studied populations, is not absolute, since a small minority of selfed eggs developed to hatch.

In a previous paper about fertilization in $B$. glabrata (Paraense, 1955) it was shown that the allosperm introduced during copulation into the female tract of a snail are stored up to be used for a number of weeks, after which time selfed eggs are laid in increasing proportion as a result of gradual depletion of the allosperm store, as represented in Fig. 3. If the snail involved were unable to self-fertilize, it would stop egg-laying on the 82nd day after copulation, as it occurred on day 70 of Fig. 1. It would be reasonable, therefore, to suppose that cessation of egg-laying in the specimens of Figs 1 and 2 had resulted from exhaustion of stored allosperm. Such hypothesis is supported by the fact that only pigmented embryos were produced by the two albino mates throughout the crossing experiments, one of such albinos being that of Fig. 1.

Geraerts \& Joosse (1984) misquoted Marcus \& Marcus (1963) as having observed production of egg masses soon after mating by the ellobiids Melampus coffeus and Detracia parana. The only passage of the latter authors that might be so interpreted reads as follows (p. 42): "In our dishes set up with material from the shore they [the spawns] were found also on the nearly dry uppermost leaves, whose level corresponds to about spring tide high water-line. Generally two spawns were laid close together, and two snails of $M$. coffeus or $D$. parana sat near them, as if they had mated recently" (italics mine).

Mating as a short-term stimulus for oviposition in snails seems to have been only observed in Helisoma duryi. As reported by
DeWitt \& Sloan (1959), two individuals isolated for 379 days without laying an egg were paired on the 380th day and egg production began within a few hours. Similar observation was made by Madsen et al. (1983) in single snails kept in isolation which, when paired, started oviposition within 24-48 hr after copulation, often laying 2-3 egg capsules each with 50-80 eggs during the first days; as in our experiments, high egg-laying occurred when snails were paired again after cessation of oviposition caused by depletion of stored allosperm.

As demonstrated by Kits (1980), ovulation and oviposition in Lymnaea stagnalis are induced by a hormone produced by the caudodorsal cells of the cerebral ganglia. Stimulation of those cells triggers a discharge which causes ovulation within $5 \mathrm{~min}$. In all likelihood such a neuroendocrine reflex also operates in $H$. duryi and in the two populations of Biomphalaria now investigated. If so, the effective factor of the mating stimulus must be sought in the allosperm. In fact, courtship and copulation occur between SSP B. glabrata and $B$. tenagophila or $B$. straminea, and between POA B. straminea and B. glabrata or $B$. tenagophila, without inducing oviposition in SSP or POA snails, whereas in these experiments the mates of SSP and POA normally lay selfed eggs. It may be concluded, therefore, that the stimulating factor must be present in the conspecific allosperm.

From the above observations it can be concluded that the two studied populations of B. glabrata (SSP) and B. straminea (POA) constitute, together with Helisoma duryi, exceptions to the general rule that planorbid snails are unrestrained self-fertile organisms. At least as concerns those two species of Biomphalaria, selfing capacity is so highly restrained in the SSP and POA snails that should be viewed as a populational rather than specific character.

Observations on the reproductive biology of basommatophoran snails reared in isolation have been confined almost exclusively to investigations on self-fertilization using samples of a few selected populations. It will not be surprising that other populations of the species herein concerned and of other species happen to show some degree of self-infertility.

\section{ACKNOWLEDGEMENTS}

To Mrs Monica A. Fernandez for technical 
assistance, and to Mr J. E. Prado for preparing the graphs.

\section{REFERENCES}

DMAE (Departamento Municipal de Águas e Esgotos), 1975. Ocortência de Biomphalaria na cidade de Porto Alegre. VIII Cong. Brasil. Engenharia Sanitária, Rio de Janeiro. 72 p.

DeWITT, R. M. \& SLOAN, W. C., 1959. Reproduction in Physa pomilia and Helisoma duryi. Anim. Behav. 7: $81-84$.

GERAERTS, W. P. M. \& JOOSSE, J., 1984. Freshwater snails (Basommatophora), p. 141-207. In A. S. Tompa, N. H. Verdonk \& J. A. M. van den Biggelaar (ed.), The Mollusca, vol. 7: Reproduction. Academic Press, New York.

KITS, K. S., 1980. States of excitability in ovulation hormone producing neuroendocrine cells of Lymnaea stagnalis (Gastropoda) and their relation to the egg-laying cycle. J. Neurobiol., 11: 397-410.

MADSEN, H.; THIONGO, F. W. \& OUMA, J. H., 1983. Egg laying and growth in Helisoma duryi (Wetherby) (Pulmonata: Planotbidae): effect of population density and mode of fertilization. Hydrobiologia, 106: 185-191.

MARCUS, E. \& E., 1963. On Brazilian supralittoral and brackish water snails. Bol. Inst. Oceanograf. (São Paulo), $13\left(2^{\circ}\right)$ : 41-52.

PARAENSE, W. L., 1955. Self and cross-fertilization in Australorbis glabratus. Mem. Inst. Oswaldo Cruz, 53: 285-291.

PARAENSE, W. L. \& CORREA, L. R., 1988. Selffertilization in the freshwater snails Helisoma duryi and Helisoma trivolvis. Mem. Inst. Oswaldo Cruz, 83: 405-409. 